\title{
AN ANALYSIS OF SYMBOLS FROM GUA CEREMONY OF OLAIA SOCIETY
}

\author{
Sergius Alpini (Corresponding Author) \\ Department of Language and Literature, Kanjuruhan University of Malang \\ J1. S. Supriadi 48 Malang 65148, East Java, Indonesia \\ Phone (+62) 85335800195 E-mail : alpiniserpin@yahoo.co.id \\ Sujito \\ Department of Language and Literature, Kanjuruhan University of Malang \\ Jl. S. Supriadi 48 Malang 65148, East Java, Indonesia \\ Phone (+62) 8179657789 E-mail : Sujito.team@gmail.com \\ Maria G Sriningsih \\ Department of Language and Literature, Kanjuruhan University of Malang \\ Jl. S. Supriadi 48 Malang 65148, East Java, Indonesia \\ Phone (+62) 85933033177 E-mail : m.g.sriningsih@gmail.com
}

\begin{abstract}
Gua Ceremony is part of Olaia tradition and an event which is interesting to analyze because there are many kinds of symbols used in it. Gua ceremony is not separated from language. By using language, we can express our thought, idea, emotion, and feeling, because language is an important aspect of human life and social communication among the members of society. It is interesting to study $G u a$ ceremony linguistically, especially in semantic. Therefore, the researcher is interested in studying this problem by formulating five researcher problems such as: how does the process of implementation of Gua ceremony on Olaia village, sub-district Aesesa, District Nagekeo, what are the symbols and symbols meaning on Olaia village, sub-district Aesesa, District Nagekeo. What are functions of Gua ceremony on Olaia village, sub-district Aesesa, District Nagekeo, and What are values appeared from Gua ceremony on Olaia village, sub-district Aesesa, District Nagekeo?

This study has two significances of the study, theoretically and practically. Theoretically, the result of this study will give the description about the symbols used in Gua ceremony. Practically, the researcher hopes this research is useful to enrich the description of Gua ceremony and as additional knowledge for people or student both from Nagekeo or others. The research of this thesis is qualitative research. It is intended to describe about the symbols, and also their meaning used in Gua ceremony. Besides the researcher himself as the key instruments, the instruments used in this study are documentation, observation, and interview. From the result of this study, it was obvious that Gua ceremony used some symbols. And every symbol has its own meaning.
\end{abstract}

Key words: Symbols, and Gua Ceremony 


\section{INTRODUCTION}

Culture is a work that is created by society that can be learned and inherited to the next generation hereditary. Culture can also be used as a tool to control human behavior. Moreover, culture can be seen as the values that are believed together in a society and can be internalized in individuals that comprehended in each behavior. So it can be concluded if the culture is a whole system of ideas, actions and man's work in the context of a society that used to humans by learning (Koentjaraningrat, 1985: 23).

Culture and society is a unity that cannot separate from one to another. Essentially culture is the result of human mind and elevating man as a creature of God is the highest among other creatures. With the culture, we can know the level of civilization of a society. But be aware that the level of culture and civilization is determined by the ability of human beings in the face of challenges around the nature or the environment in which people live.

According to Kessing (1981:135) human and society has developed in accordance with the specific stages that began with the simplest form, complex to the extent that simple. Every tribe in Indonesia has different rules to regulate the lives and relationships among community members.

Fernandes (1989: 150) says that the custom is a discipline that is used to regulate the relationship between man and man, and man with the souls of their ancestors. While Gazalba (1985: 156) suggested that the custom is a normative habit, a habit born in response to the new conditions. If conditions change again, a habit that has become customary, still form properties of the supporters. Customs is to regulate all aspects of human life, so that man cannot be free of customs rules wherever he is.

From concept above shows the social norms, religious powerful and complex.
Traditional ceremony which is held by a public sighting of religious beliefs and practices. Traditional and community relations are closely related, because customary law refers to the community as well as having a very important role. Thus every member of society should be worth the customary rules. Deviations done, will make a person regardless from the environment wherever he is.

According to Machmoed (1971:3) "culture or civilization is that complex whole which includes knowledge, belief, art, laws, morals, customs, and any other capabilities and habits acquired by man as a member of society". In this case, he said that culture as a totality which appears by the sum of social life in society. By those various fields, it can be decipherable as culture.

In semantic relation, Olaia is very incredible and interesting to be learned about everything in language and so is the culture. The native speakers produce word, not only in spoken form but also in written form. The people of Olaia make a communication among one to another by use Olaia language which it has own rules, forms and linguistic elements such as morphology, semantics, syntax, and phonology. Moreover, even there is only one village that has a little differets language with others but Olaia language still the main basic character. There, many things are related to the culture ceremony that has symbols and also message meaningfully. In this case, by understanding the symbol we will know the meaning of that symbol absolutely. In this study, the researcher would like to observes about Gua ceremony as one of culture ceremonies in Olaia village especially on symbols and the meaning of symbols. Here, the researcher wants to learn more and more about semantic which as a subject learning about meaning on language, marks, symbols, sign, and so on. To connect the semantic study with the writer's research because it is related to the meaning. Semantic 
is study about meaning in language. We know that meaning is a part of the language where people communicate or make some conversation each other and it produces the meaning of language itself. Meaning is produced not only in a language, but also in a certain symbols, marks, signs and so forth.

Elements of culture consist of language, social organization, knowledge systems , systems and technology equipment life, livelihood systems, religion and art system ( Koentjaraningrat, 1985: 294). One example of culture in society is Gua (circumcision) ceremony. Gua ceremony is a tradition that has been around a long time and going on until now in Olaia society because of various reasons such as religious and socio-cultural.

One of the Flores' people who still practice male circumcision (Gua) is village society Olaia. Olaia village is a village located in the district Aesesa, sub-district Nagekeo . Olaia society known as abiding society and adherence to religious teachings, which most people embraced Catholicism. In the village Olaia there are also several religious institutions that affect their lives. Besides adherence to religious teachings, Olaia society also holds fast to the traditions and customs, one of them is Gua ceremonial. The tradition has been carried hereditary until now and continue to be made as a part of Olaia society life. Gua tradition in Olaia Village estimated to occur since prehistoric times was observed from the pictures in the cave from the Stone Age. The reason is still unclear at that time, but the theories predict that this action is part of a ritual sacrifice or offering, a sign of surrender to God Almighty, a step towards maturity, a sign of defeat or slavery, or attempt to alter the aesthetics or sexuality.

The existence of the Gua ceremony ( circumcision ) is formed or assumption prevailing in Olaia society. Gua (circumcision) that occurred in Olaia generations occurred and is still carried out until now by society based on several aspects such as religion, social and cultural.

Olaia tribe has a lot of culture, such as, Etu ceremony, Kose ceremony, Gua ceremony and so on. Therefore, the researcher limits the discussion only on cultural issues Gua ceremony. Especially about symbol, functions and relevance to the Olaia society.

There are several reasons why the researcher interested to observes about symbols used in Gua ceremony. First, to know the symbol, because there are many symbol used in this ceremony. Second, the researcher wants to know more specific about the symbols meaning of this ceremony by use a semantic study because it is related to the meaning itself. Third, to know the values and values meaning that revealed from Gua ceremony, and increasing the knowledge of the people on cultural especially about Gua ceremony in Olaia village.

Research on symbols of Gua ceremony in Olaia village, sub-district Aesesa, District Nagekeo is expected to provide benefits are:

- Theoretically

The purpose of this study is to get the result that will give the description and understanding to all of students about symbols and symbols meaning used in Gua ceremony.

- Practically

From this study of symbols used in Gua ceremony is also expected can become a cultural knowledge that is useful for the people in this country, and especially for students of English Literature in Kanjuruhan University who want to learn about this study.

\section{REVIEW OF RELATED LITERATURE}


Literature review is basically a theory and the concept of absolute scientists used in the writing of science or research that can be tested truth. Therefore, this paper is the literature on the study " An Analysis of Symbols from Gua Ceremony of Olaia society". So, in order to maintain the validity and complexity of the culture, the researcher try to discuss about the culture related to the title of writing, among others: culture, customs, language, relation between culture and language, symbols, traditional ceremony, and previous of study.

Culture as a result of the human mind, in terms of the various forms and manifestations is known throughout history as the man who does not belong to a rigid, but constantly evolving and changing, foster human to adapt to cultural changes and challenges the traditional age to enter the modern era.

\section{The relation between culture and language}

The relation between culture and language is that structure of the language determines the way in which speakers of that language view the world. A somewhat weaker version is that the structure does not determine the world-view but is still extremely influential in predisposing speakers of language toward adopting a particular word-view. (Ronald 1998: 216)

\section{Symbols}

Symbols are having a good many forms. Spoken and written words are familiar examples. But, we also communicate with object; in the most societies, masks, hair styles, clothing's, body adornments, tattooing ribbons, veils, medallions, or other devices serve to communicate the social status of the wearer and gravity of an occasion. Colors often have symbolic connotation: in the western world, "red" brings to mind anger (and communism), "blue" emotional depression, "yellow" cowardice, "white" purity and innocence, "black" evil and mourning (although among black, there has been a recent trend to reverse the traditional symbolism by associations "black" with goodness and "white" with badness (Williams, 1971: 69).

\section{Gua ceremony}

Gua ceremony (circumcision) is as one of the cultural treasures that need special attention from the anthropology, although the focus of their attention is not perceived directly. However, their studies of impression other cultures have in common with our local culture indicates that culture and traditions with their customary rituals exist and live among certain communities also (Manners, 2005:

Therefore, confidence in the traditional ceremonies are still attached to the community, especially in rural communities Olaia, then they do not let go of the traditions and customs of the ancestors, it is not surprising that the ceremony was still coloring the villagers.

In a ceremony is generally a party arranged by the norms and customs, the party is simply a ritual feast is arranged according to the traditional customs of the society in order to commemorate important events or with the relevant customary provisions (Aryono, 1985: 423).

\section{Gua ritual ceremonies}

Gua ritual ceremonies conducted in rural communities Olaia religious practices to maintain a balance with the highest form of human ancestor between humans and humans to humans. Gua traditional ceremony is also one that is based, understood and internalized by Olaia rural communities that will benefit their lives. Therefore the ceremonial Gua passed from generation to generation by our ancestors from generation to generation.

\section{METHODS}


In this study, the researcher uses a method which is based on the intention of this study. Here, the method that will be adopted in this research is qualitative method and descriptive (ethnography) approach. It is a method that is commonly applied in social studies, culture studies and literature studies. Qualitative research is based on a naturalistic research, ethnography research, case research, and analysis research.

Malinowski (1922:373) qualitative research is concerned with understanding of the social phenomenon from the participant's perspective. Understanding is acquired by analyzing the many contexts of the participants and by narrating participant's meanings for these situations and events. Participant's meanings include their feeling, beliefs, ideas, thoughts, and actions. In this case, he stated that a qualitative research is basically related with the understanding from the perspective of people in social phenomenon. Here, the researcher will analyze many kinds of context of the participants by telling the situation and events based on their feeling, ideas, thoughts, actions, beliefs and so forth.

\section{Data and Source of The Data}

In this part, the researcher decided to uses $G u a$ ceremony as a subject of this study. To get the data, the researcher would like to make an observation directly to the subject itself. In this subject, the researcher still does not yet know well about the process of Gua ceremony and especially about those symbols and symbols meaning used in that ceremony. Therefore, the researcher would like to observe about the symbols used in Gua ceremony. Furthermore, as the object in collecting the data, the researcher will get from personal experience, the informants, Mosalaki (a person who really know well about Olaia culture), and also from socialite. Here, the researcher hopefully in this observation will accurately obtain the data as validity and reliability data as possible.

\section{Instrumentation}

The main instrument of a qualitative research is the researcher himself. In collecting the accurate data, the researcher will use some of instruments as a technique to obtain the data. And these instruments are observation, documentation, and interview.

\section{Data Collection}

To collect the data in this thesis, the researcher gets the data from subject and the object by using different techniques such as from some books, internet, and of course from the informants. The data in this thesis were collected from some books not only about culture but also the understanding about the symbol and meaning itself, and then the writer gets the data from the internet concerning with the thesis and also from the informants who really know well about Olaia culture specifically in Gua ceremony.

\section{Data Analysis}

In this part, it will be done after the data had been collected by the researcher. The writer has to analyze and classify the data and then the writer may begin to write the thesis. Moreover, the writer also has to consult the data with the informants in order to check the misinterpretation of the data.

For this study, the researcher analyzed all the data taken from the result of the interview in that observation. Then, after collated the data, the writer takes some steps in the data analysis, as follow:

a. Finding some sentences that contain symbols and analyzing them.

b. Translating the symbols into English 
c. Grouping the symbols.

d. Describing the meaning of that symbols, and

e. Drawing the conclusion for the data analysis.

\section{Trustworthiness of the Data}

In this section, the researcher uses triangulation on his thesis. Triangulation is one of important techniques that is used by the researcher to measure whether the data can be trusted or not. In this case, the researcher has to make a communication with other people in comparing notes to extend the researcher's mind. Here, there are a few steps used in this technique to make sure that the data is still valid. Firstly, the researcher watches the video of the ceremony in order the data he collected are appropriate with source. Secondly, the researcher consulted the data with informants to check the misinterpretation of data and ensuring whether the data that given by informants has been corrected or not. In the end, the researcher discussed the data that he got with some friends for getting the different ideas which useful for his expanding analysis and also asking for opinion from the "Mosalaki".

\section{Findings}

Process of Gua Ceremony :

\section{'Oko Utu',}

At this stage, the core families rituals $G u a$, invite families who still have relatives either blood relations or to get together and to consult and exchange views together concerning the implementing strategy ceremony ceremony. They are $k a^{\prime} e a z i$ (sisters) who participate directly in the activities of "oko utu" (converge to customary deliberation) and $E b u T a^{\prime} u$ (families parties girl or mama).

\section{'Ngalu Pare',}

The opening ceremony of whole series of events begins with the ceremonial ritual Gua "Ngalu Pare " or "First Fruits ", which is a ceremony in which the candidate Ana Gua was inaugurated in traditional rituals become "Ana Gua". The main actor in the ceremony Ngalu Pare is Ebu Ta'u and Ana Weta. On the appointed day, they come together to bring each part dependent on the agreement by the family council.

After all the families present, especially Ebu Ta'u and Ana Weta, straight held animal sacrifice cutting ceremony, pigs carrying the Ebu Tau. Currently swung machete to slaughter pigs, following sacred sentence : " pedhu Benu zi'a ura, ura nai nata, nata kebha-kebha, kami tau Nuwa mo ko ana loge kami ", which means: " we ask for instructions good for the next life of our children who will carry out the ceremony maturation itself and beg the smooth implementation of this ceremony".

Sacrificial animals were burnt and split; the heart was taken and immediately examined by an astrologer that a seasoned traditional leaders. Based on the markings on the victim pork liver, predictions can be made about the process of reciprocation of the journey of life "Ana Gua " at a later date.

After that, proceed with the filling of rice in a basket or "Zase Zea" and the show dressed in traditional clothes (Pake Pela) on Ana Gua. This is simply done by Ebu Tau greeting accompanied prayer request for a blessing at the time put it on Ana Gua: "Weki zia lo molo " which means : hopefully healthy body and longevity. Since ceremony Ngalu Pare, Ana Gua must obey any restrictions, such as not travel far. If Ana Gua married then she should not serve her husband in all things; everything was booked entirely on "Ana Kaju Ae ". The fire in the furnace of his house should continue to have embers and should not be extinguished. All these demands must be 
adhered to in order to maintain at the same time to avoid disaster or threats to themselves "Ana Gua". In addition, prepared a " Manu Lalu Toro " or the red rooster, which is tied at Ana Gua home during the ceremony took place. The rooster is a symbol of courage of Ana Gua. At the time of important ceremonies, especially when the show "Pemu ", the cock crowed in guarding against, when crowed it bode poorly.

\section{"Pogo Dhoge Tau Alu"}

This stage is the stage in the form of activity to makes a mortar and pestle pounder. All men who have undergone the Gua rite trooped off to the forest to look for jackfruit or mango tree to be used as a mortar and root old bamboo as a pestle. After completion of the work, along with a mortar and pestle brought festive parade into the village, then held the cooling ceremony with slaughter a pig or chicken. Splash blood in the mortar and pestle as a sign that these tools are used to pound rice decent preparation of Gua ceremony.

\section{"Wari Dho",}

"Wari Dho " meaning dry in the sun and mashed. At this stage a feast of rice preparation is taken out of the barn, dried for a day and then refrigerated for two days. After that, the family implementers held a party amicably approach to invite "mama-mama" and girls in the village (Ana Weta Keka Bo'a) to come together in a spirit of brotherhood for pounding rice. They grind together accompanied by folk songs (Manu Keka) and in the vibrant sound of jingling bells and colorful tassel that hangs on a pestle and mortar, so the atmosphere ahead of the party seemed crowded.

\section{'Giru U'u',}

" Giru U'u " means rice which result from the collision destroyed almost resembles flour. The ceremony was held after the finished of activities pounding rice. Rice result of the collision sifted, then made a separation between the rice is not good, which was almost destroyed by the impact. This poor rice (Giru U'u) cooked all and eaten by all the villagers (Keka Bo'a), especially by women and girls who have willingly pounding. Usually sheep or pigs slaughtered as a side dish. Eating together is more an expression of gratitude to the family of those who willingly help ease the burden of family organizers responsibility of Gua party.

\section{'Ghoro Bheto Rona Bale",}

"Ghoro Bheto Rona Bale " means pull bamboo to make camp. This stage in the form of activities to cut bamboo in the forest and pulled into the village as a material to build a small camp (bale) temporary shelters for Ame, Ana Gua and Ine. The camps are mostly made of bamboo, thatched palm leaves and only be undertaken by those who had undergone the rite of the Gua. This work was completed before the afternoon. Location of the camp should be in the middle of the village in order not to be released empty, but still maintained the traditional song and dance around the place. The small camp serves as a place for meditation and coaching, where Ana Gua was given a lot of discourse, the pious counsels, and others of Ame and Ine.

\section{"Enga Ame"}

At this stage, the head of the Indigenous (Ame) who take on the role as master of ceremonies, as agreed in the traditional meeting, which has been approached personally and has expressed willingness, formally invoked through traditional ceremonies. Some Old Customary (Kaka Logo), and all the envoy of each participant rite of Gua go together invite or summon the Ame (Enga Ame). Ame picked up at the gate of the village by Gua participants then paraded into the village with singing and traditional dancing. Had the Ame residing in the same village, he immediately picked up by all the participants from his home. Then they 
gathered in a house. On the same occasion, Ine join. Since then, the existence of the Ana Gua handed over entirely by the family to the Ame responsibility.

\section{"Bhego"}

After finishing the activities "Enga Ame", followed by a ceremony "Bhego" (scolds ) that day, precisely in the afternoon. All families began arriving carrying luggage each nuclear family Ana Gua home. Ame provided an opportunity for Ana Gua for each departed to his house in order to prepare all the things that need to be prepared for the next event. Ebu Ta'u parties dressed in traditional clothes soon default on Ana Gua include weapons such as kris and chopsticks. Family eldest Ana Gua (Ngalu Ga'e) prepare clothes that will be worn by Ame form: : Wo'i, Tali Watu dan Lesu (custom fabrics, bere small and headbands), while the link, in this case "Kaka Logo" busy monitoring all the preparations. After all the preparations completed, at a predetermined time together, each family out of his home deliver Ana Gua to gather at a place in the village. Furthermore, the Ana Gua and Ine festive parade to the tent (Bale), stay there and not be allowed to exit the tent except command of Ame. At night held on night duty .

\section{"Pemu"}

"Pemu" means to join or assemble, is the peak of rites Gua implementation. Before sunrise, Ame together with Ana Gua that is complete traditional dress quietly left the camp and went to hide in the forest; while Ine remain in the tent, keeping the fire to keep it burning. In the afternoon, each family of Ana Gua busy cooking bamboo rice in a field in the village. Finish cooking, some helpers (Kaka Logo) went to the forest to look for Ame together with Ana Gua to enter the village, to a ceremony called "Nabe". There, the whole family is ready to welcome them.
Before entering the territory "Nabe", they must first hold a rite in a place called "Repu" where there are two parallel anchored bamboo sticks as poles, palm leaf roof. Around Repu stretched woven mats of palm leaves and pillows from pandan leaves to each Ana Gua. His place has been prepared five pieces of rice bamboo and bowl wine (tobho) . Entering Repuh territory, they have to walk slowly, concentrating, should not be turned to the left and to the right and to be careful around the Repuh five times, then sat around it. The situation very quiet and tense. The Ame instantly create a rite called "Pazo Zeta", namely: "'Uta Bhari Tu'u Rusa Bene, Tua", " (Kastela, dried reindeer meat and wine) mixed while reciting the following sacred:

"Da ipa weki kau ngaro ngato, da ana weta ine ame kau dhegu regu dhugu rugu".

Meaning :

" if it is still in-law relationship, you may be eager to marry her, but if they touch our brothers and sisters, or mother, is strictly prohibited,".

Then Ame take two pieces of bamboo rice and square off eating five times, then the Ana Gua directly imitate it, then put it back; as well as wine beverages stored in "Tobho". Afterwards they stood. Ame as the primary guide followed Ana Gua eldest and so on until the youngest, moving more slowly around Repuh five times, and straight out to where a second ceremony, "Nai Nebe " (ride over a large stone shaped flat), the Ame taking distance from Ana Gua; standing at a distance. The Nabe, has stood the customary two parents, which is a special officer who will perform a circumcision ceremonial. A body brace Ana Gua served as the, while others perform a ceremonial act, holding a knife and a piece of wood rosin. Before Nai Nabe, Ana Gua undressed, except for a small piece of cloth (sada) remained entangled in the waist. Furthermore, one by one Ana Gua forward sitting on Nabe, and the clerk immediately carry out ceremonial duties. The cloth (sada) covering the genitals, opened a 
little, then a knife and wood rosin pushed to the genitals, at the same meeting in splash with blood of the lamb as a symbol of circumcision $(G U A)$.

Meanwhile, all those present, especially the adult males together shouting " meze,,,, meze,,,,meze "means big or mature. The father rejoined her children while walking together in the order, heading home coaching (Bale). The next day, early in the morning they left the tent again, village exit: cultivated not seen. They go where there is water to soak away. Since then, the cooked food should not be eaten, they are only allowed to eat raw food.

\section{"Tapa Uwi"}

"Tapa Uwi" (roasted potatoes). At this stage, each family of Ana Gua burn forest potatoes can be eaten at the same place when cooking rice bamboo. After completion of burning potatoes, all preparations completed around noon, connecting in this case "Kaka Logo" set out the time to call Ame and Ana Gua. Arriving at the village, they were greeted as usual and immediate family in conductivity towards Repu while walking around the Repuh five times, then sat on the mat. Ame take roasted sweet potatoes and sugar cane that has been prepared family, square off eating five times and imitated by Ana Gua. Then they stood up and walked again around Repuh five times while holding the sugar cane, while potatoes left. After that, it's time the "Toli Tewu" (throwing cane). Target throw is a sister-in-law of Ana Gua itself. Each Ana Gua pretend indifference walking among the crowd, looking for where the position sister-in-law. The throw must be done abruptly. Usually the atmosphere is very lively when the throw on target. By evening, they had to be in camp to continue coaching the show and "Laku Tapa".

\section{"Zeta"}

Zeta stage is the stage of trials, whether an adult or not. On the third day after the core ceremonial (Реmu), early in the morning when the cock crowed for the second time, the Ame with Ana Gua out of the tent and stood outside. Each Ana Gua ordered by Ame chopsticks into the air to pass through the camp. If between Ana Gua chopsticks do not pass through the camp, it could be predicted that in the near future he will come to harm. Done chopsticks continued with the "Zagho Manu", in which Ana Gua went to his sister's home each for chopsticks chicken. Exactly at the appointed time, they regrouped carrying a blowpipe and submit the results to the "Ana Kaju $A e^{\prime \prime}$ to be processed, while they sit in a circle on the lawn tent, enjoying breakfast of ripe bananas and coconut water, before heading into the forest. Meanwhile, in the afternoon, the family resumed their duties bamboo rice cooking. Once everything is completed, connecting (Kaka Logo) call Ame and the Ana Gua that entered the village and the immediate surrounds Repu five times, then sit in a circle. Ame doing little rites "Pazo Zeta, Pasa Tai", which spells the agreement, then took a bamboo rice and meal square off five times, and followed by Ana Gua.

Rice is released and they stood up to walk again surround Repu five times, so go out to the tent to eat along with a side dish of chicken meat blowpipe results of Ana Gua. After the meal, held a ceremony dismantling tents.

\section{"Tu Ana"}

At this stage, Ame together with Ana Gua, Ine, the Old Customs and other family members of Ana Gua, singing and dancing traditional together, deliver at once handed over Ana Gua to his family respectively. Arriving home, birth father of Ana Gua has been prepared to stand at the front door of the house, holding the rice and cold water "Zea Ka, Ae Kete".

At the time of his stepping on the stairs of the house, water and rice spilled on 
the head of Ana Gua while uttering the following sentence:

“Ine pese Ame na'u, kau ne kono kopo, kau ne tama mada, kau tadu ne teka, ngi'i ne le'e, kau weki ne zi'a, lo ne molo, kau dhadhi ne woso, meza ne kapa tina ne bi welu ne nge".

This means:

"Message mother, father tell you that you have entered the house and into a fence, you have sharp horns and pointy teeth, nice bodied and healthy, you are able to populate and can maintain it successfully".

Ana Gua allowed to enter the house, took off his royal garments and other attire which has been prepared by the family, and then immediately re-joined in line together deliver his other friends. After that, all gathered back home Ana Gua eldest (Ngalu $G a^{\prime} e$ ). From there they dispersed to prepare all the needs and requirements related to the "Padhi" ceremony .

\section{"Padhi" Ceremony}

"Padhi" (parallel). The ceremony is held on the fourth day after Pemu. Each family of Ana Gua brings a basket of rice and beef. Parties members gathered amid the village and lined up in the order. Furthermore, a special team led by an Old Ceremony with receiving two handfuls of rice and meat of each Ana Gua to be distributed every existing homes in the village for each Ana Gua. Endeavored that get it all home. The intention to divide the rice and meat eating together as a sign of greeting or gratitude and thank the entire family as well as the closing ceremony of a series of Gua events.

\section{"Tu Ame"}

"Tu Ame" (usher the father), at this stage, some Old Indigenous, Ana Gua and their families usher departure of the Ame at the border of the village. In subsequent trips, Ame accompanied by two Old Ceremony. If Ame comes from the same village, then he will be escorted to his home by all participants. As an expression of gratitude, each Ana Gua handed the gift to Ame. Giving it can be a sheep, goat, cow or chicken.

\section{Symbols in Gua Ceremony}

Oko Utu is an early stage that must be pass before entering the next series of events in relation with a traditional ceremony. In this occasion, whole families, both families are far and near, families neighbor or acquaintance ("keka bo'a, te'e meze lida lewa") come together and negotiate into the mature and wise, by considering various possibilities, then jointly took the decision to carry out Gua ceremony with full responsibility, so that this ceremony can be successful. Courage and roundness ideas taken as a benchmark the implementation of the party. Symbols of activity "Oko Utu", is unity, kinship, brotherhood and responsibility. However, the more prominent is the value of unity, particularly the unity of ideas or opinions, because there is some activity deliberations to reach a consensus.

Wari dho The activity of "wari dho" is synonymous with activity "rona bale" and " pogo dhoge tau alu ". The differences are, "wari dho" done by the girls and women, while "rona bale" and "pogo dhoge tau alu" done by men. Symbols of this activity is mutual help, cooperation or mutual assistance without demanding a reward or remuneration, with one particular intention to ease the burden of Gua ceremonial family life.

Every members of Nataia society realize this, that someday they will have trouble and need the help of fellow citizens, so, for Nataia society, the attitude of mutual cooperation is not an obligation but as a consequence of the fundamental virtues of living together: a virtue heritage.

Pemu "Pemu" is a culmination ceremony of Gua ceremonial. "Ame" and "Ana Gua" 
left the tent, silent, experiencing loneliness in the wild at the same time reflect, breathe as well as a new power as a preparation before entering the next ceremony. It is coming from the notion that " during the transition from one level to the level of living life to another, or from one social environment of the social environment to another, is a critical moment, full of dangers, both real and supernatural. Traditional ceremonies contain elements of the rejection of that supernatural threaten people and the environment ". Starting from the belief that each "Ana Gua" must prepare as well as possible. In this occasion, fortitude, perseverance and seriousness gets top priority. Mistakes made during the ceremony, will be fatal for a lifetime.

Another value that the researcher wants to quote is the ascetical, that is a matter of selfrestraint that mental resilience against less serious attitude (childish) towards an adult and mature attitude. Because at this moment, people will experience a crisis of confidence: He felt mentally challenged and raised doubts and anxiety in themselves faced with the same choice opportunity: going to work or not. For every "Ana Gua" should really motivated and try to show their commitment to continue to work, to achieve success expected, reaching maturity and maturity demonstrated fully that should begin on the occasion of this ceremony.

Another part of the core ceremony is the banquet together. In this banquet, there was agreement, as well as the oath of "Ana Gua" to the highest form of allegiance and obedience to statutes fully proclaimed by "Ame" which reads' "da ipa weki kau ngaro ngato, da ana ine weta mame kau dhegu regu dhugu rugu' ', means "if there is a relationship-in-law, you may be eager to marry her, but if there is still a relationship brothers and sisters, or mama prohibited ". Breaking a promise and oath that means accepting a curse in such a catastrophic plague. Here, the element of obedience religious is a major concern.
Zeta It is believed that after a "Pemu" ceremony is seen as the climax traditional circumcision ceremony, the parties concerned have gained a certain strength and is rated as a grown man. Maturity theirself it can be measured again in a special test that is doing the blowpipe into the air, passing through the roof of the tent. Furthermore, each "Ana Gua " went to the sister 's house for chicken chopsticks.

Blowpipe result is a symbol that would show that they have been able to produce its own and deserves to live independently

Padhi The ability and strength of "Ana Gua" distributed to all villagers in the form of rice and meat of any "Ana Gua". Aside from being a force distribution, measures were also handing out a charitable cause at the last supper together all the villagers in a Gua ceremony. Furthermore, it also contains the deepest meaning which each "Ana Gua" would like to express their gratitude and appreciation for the participation of the villagers during the event, as well as the blessing, so that prayer request as well as the ability of self-existence which has been obtained it is recognized and maintained together for the development of personality "Ana Gua" itself as well as the welfare of society at large.

\section{Functions Of Ritual Gua}

For Health The physical state of a person is an essential element for the implementation of activities in all aspects of the next life. According to Nataia society, after holding the rite Gua, a person is considered a healthy body and spirit; because at that time all the diseases in themselves expelled (pui una teba Beza gha, lo'i Petu zaza" which means "removing the damaged skin and all the irritation, freeing themselves from the pain" symbol expulsion of the disease is made by throwing a piece of sugar cane to a family member who is no relation to Ana Gua sister-in-law. So, all the elements 
that are less well inside Ana Gua delegated everything in sister-in-law.

For The Maturation Principal motivation rituals Gua in Natalia society is to mature self (ga'e Weki lo Nuwa), namely that a person is no longer called little child (ana wa nguza). Someone will be judged as adult men and mature through this rite. A greeting as an adult is very happy; someone felt himself lifted nature and feel worthy of taking care of any customs, including Gua traditional for family members who are minors or who have not undergone the rites of the Gua. He is considered to be quite mature and wise to organize next life, honored, respected, has the right to participate actively in official meetings customs, recognized personal authority as well as having a great influence in society. Based on this assumption, and strengthened by concrete life practice every day, then every family with a maximum of heroism trying to raise capital for the sake of the implementation of the Gua ceremony, although often perceived very big consequences.

\section{Meaning and Value of Gua Ceremony in General}

Each person would crave a ideal personal profile that is expected to become a mature personality, is not limited to maturity in the sense of physical, emotional and mind, but mature in terms of whole life attitude as expressed in the attitude of responsibility, selectively choose and decide with wisely and have a clear conscience, dedicated and free from all selfishness. The realization of the ideals mentioned above certainly in dire need of a pattern, the way and the best method to bring a human adult and mature personality. According to Nataia society, to produce a person's behavior is genuine adult personality, among other necessary rite Gua implementation, which is believed to be the most valid means, moments full of meaning and value constructive: a reliable mode that deliver people to the purpose of life completely.

\section{Conclusion}

Conclusion The researcher concludes that Gua ceremony is an event which shows significant phases of life: birth, marriage, and death. Gua ceremony is rich of symbols. It is a beautiful event to participate.

There are some terms used in Gua ceremony, that is kae azi which means sisters. Ebu ta'u is families parties girl or mama. Ana weta are siblings and cousins that the relationship from seen from grandfather to the father. Ame means father and Ine means mother. Manu lalu toro is red rooster. Keka bo' $a$ is all the villagers.

Symbols that are used in the Gua ceremony are reflection on actions, language, social life, and the means of livelihood of Olaia society. The symbols which are used are like; oko utu, is symbol of unity, kinship, brotherhood, and responsibility. Wari dho is symbol of mutual help, cooperation or mutual assistance without demanding a reward. Pemu, is symbol of maturation. Zeta, is symbol of responsibility. Padhi, is symbol of thanks, , pray, wealth.

\section{Suggestion}

From the explanation above, the researcher considers that this study is new at Kanjuruhan University of Malang in the language field, especially English Literature. The researcher suggests that it can give a description as information to the reader about the symbols that are used in Gua ceremony.

Because Olaia society has many kinds of ceremony, so the researcher hopes to other researcher who may analyze Gua ceremony can use this thesis for guidance to the next analysis in different aspect. Beside the Gua ceremony the other researchers can study about kose ceremony, birth ceremony process, etc. 


\section{Jurnal Ilmiah Bahasa dan Sastra \\ ISSN : 23557083 \\ Volume 3 Nomor 1 Juni 2016}

The researcher suggests, that the readers who want to analyze the Gua ceremony can add their theory from other sources that do not only include in this thesis but also from other references. Then, the researcher hopes the students of Kanjuruhan
University of Malang especially the student from Nagekeo are interested to study Gua ceremony especially about literary devices used on Gua ceremony.

\section{References}

Aryono ( 1985 ). Antropologi Budaya. Jakarta Gramedia.

Fernandes ( 1989 ). Kebijaksanaan Manusia NTT Dulu dan Kini. Ende: Nusa Indah.

Gozalba ( 1985 ). Pengantar Kebudayaan Sebagai Ilmu. Yogyakarta: Kanisius.

Kessing ( 1981 ). Antropologi Budaya. Jakarta: Erlangga.

Koentjaraningrat ( 1985 ). Manusia dan Kebudayaan Indonesia. Yogyakarta: Djambatan.

Machmoed ( 1971 ). Antropologi Budaya. Jakarta: Gramedia

Malinowski ( 1922 ). Metode penelitian Kualitatif. Yogyakarta: Raka Sarasin.

Manners ( 2005 ). Teori Budaya. Yogyakarta: Pustakan Relajar.

Ronald ( 1998 ). Language and Culture. New York: Oxford University Press.

William ( 1971 ). The Heritage Illustrated Dictionary. New York: American Heritage Publishing Co. Inc and Houghton Mifflin Company. 